\title{
PENGARUH SISTEM PENGENDALIAN INTERN DAN PENERAPAN SISTEM AKUNTANSI KEUANGAN DAERAH TERHADAP KUALITAS LAPORAN KEUANGAN PEMERINTAH KABUPATEN INDRAGIRI HILIR
}

\author{
IRA GUSTINA \\ Universitas Islam Indragiri Tembilahan \\ Email : iragustina85@yahoo.co.id
}

\begin{abstract}
This study aims to determine the effect of the Internal Control Sistem and the Implementation of the Regional Financial Accounting Sistem on the Quality of Financial Reports of the Indragiri Hilir Regency Government at the Indragiri Hilir Regency OPD. The population of this research is the Head of Subsection of Finance and Finance Treasurer and the sample in this study was 50 questionnaires. The data analysis method used was multiple linear regression, classical assumption test was used to test data normality, multicollinearity and heteroscedasticity. Descriptive statistical testing, t-test hypothesis and coefficient of determination $\left(R^{2}\right)$. The results showed that Partial test of the Internal Control Sistem has no partial effect on the Quality of Financial Reports at OPD Indragiri Hilir Regency. The Regional Financial Accounting Sistem has a partial effect on the Quality of Financial Reports at OPD Indragiri Hilir Regency. Adjusted R Square value of 0.349 means that there is 34.9\% of the influence of the Financial Statement Quality variable is influenced by the Internal Control Sistem and the Regional Financial Accounting Sistem, $47.1 \%$ is influenced by other variables.
\end{abstract}

Keywords : Internal Control, Regional Financial Accounting, Quality of Local Government Financial Reports

ABSTRAK
Penelitian ini bertujuan mengetahui pengaruh Sistem Pengendalian Internal Dan Penerapan Sistem Akuntansi Keuangan Daerah terhadap Kualitas Laporan Keuangan Pemerintah Kabupaten Indragiri Hilir Pada OPD Kabupaten Indragiri Hilir. Populasi penelitian ini Kasubbag Keuangan dan Bendahara Keuangan dan Sampel dalam penelitian ini sebanyak 50 kuesioner. Metode Analisis data digunakan adalah regresi linier berganda, pengujian uji asumsi klasik digunakan uji normalitas data, multikolinieritas dan heterokedastisitas. Pengujian statistic descriptive, hipotesa uji $-\mathrm{t}$ dan koefisien determinasi $\left(\mathrm{R}^{2}\right)$. Hasil penelitian menunjukkan bahwa secara parsial Sistem Pengendalian Intern tidak berpengaruh secara parsial terhadap Kualitas Laporan Keuangan Pada OPD Kabupaten Indragiri Hilir. Sistem Akuntansi Keuangan Daerah berpengaruh secara parsial terhadap Kualitas Laporan Keuangan Pada OPD Kabupaten Indragiri Hilir. Nilai Adjusted R Square 0,349 artinya bahwa terdapat 34,9\% pengaruh variabel Kualitas Laporan Keuangan dipengaruhi oleh Sistem Pengendalian Internal dan Sistem Akuntansi Keuangan Daerah, sebesar 47,1\% dipengaruhi oleh variabel lain. Kata Kunci : Pengendalian Internal, Akuntansi Keuangan Daerah, Kualitas Laporan Keuangan Pemerintah Daerah

\section{PENDAHULUAN}

Dalam setiap prosedur dan unsur dalam suatu sistem untuk menerbitkan laporan keuangan yang berkualitas harus ada pengawasan dan pengelolaan keuangan yang baik. Pengelolaan keuangan dalam suatu pelaporan yang disusun tentunya harus sesuai dengan peraturan perundang-undangan yang berlaku (bpk.go.id, 2018). Laporan Keuangan Pemerintah Daerah (LKPD) merupakan produk dari pengelolaan keuangan pemerintah daerah. LKPD yang disusun diakhir periode merupakan bentuk pertanggungjawaban pemerintah kepada publik/masyarakat. Komponen laporan keuangan terdiri dari LRA, Neraca, LPSAL, LO, LPE, LAK dan CaLK dimana penyajiannya berdasarkan Standar Akuntansi Pemerintahan (SAP). Pelaporan tersebut diatur dalam Peraturan Pemerintah Republik Indonesia nomor 71 tahun 2010 tentang standar akuntansi pemerintahan. Dengan adanya penyajian yang disusun dengan baik dapat menjadi bahan evaluasi kebijakan bagi pemerintah daerah dalam pengelolaan sumber dana baik dalam penyajian informasi pelaporan finansial, realisasi anggaran dan penilaian kinerja finansial.

Laporan keuangan pemerintah yang baik menurut Peraturan Menteri Dalam Negeri Republik Indonesia Nomor 64 Tahun 2013 harus mencakup empat karakteristik yaitu relevan, handal, dapat dibandingkan dan dapat dipahami. Laporan keuangan yang disusun harus memenuhi prinsip-prinsip yang dinyatakan dalam Peraturan Menteri Dalam Negeri Nomor 64 Tahun 2013. Laporan keuangan pemerintah dihasilkan dari masing-masing Organisasi Perangkat Daerah (OPD) yang kemudian dijadikan dasar dalam membuat laporan keuangan pemerintah. Setelah dikonsolidasikan menjadi Laporan Keuangan Pemerintah Daerah (LKPD) tidak langsung dipublikasi namun diperiksa terlebih dahulu oleh Badan Pemeriksa Keuangan (BPK). Tujuan umum laporan keuangan sektor publik menurut Mardiasmo (2012), adalah kepatuhan dan pengelolaan, akuntabilitas dan pelaporan retrospektif, perencanaan dan pelaporan otorisasi, kelangsungan 
organisasi, hubungan masyarakat dan gambangan. Laporan keuangan yang berkualitas menunjukan bahwa kepala daerah bertanggung jawab pengelola organisasi

Dalam menyusun Laporan Keuangan tentunya membutuhkan skill dan kompetensi untuk menjaga dan meningkatkan kualitas dari laporan keuangan dimana banyak kasus yang menyebabkan rendahnya kualitas laporan keuangan pemerintah. Beberapa faktor yang menyebabkan rendahnya kualitas laporan keuangan pemerintah daerah disebabkan adanya kelemahan sistem pengendalian intern, belum tertatanya barang milik negara/daerah, penyajian laporan keuangan yang belum sesuai dengan standar akuntansi pemerintah (SAP).

Dalam ruang lingkup tata kelola keuangan pemerintahan yang menerapkan Standar Akuntansi Pemerintahan (SAP) akan memberikan penyajian laporan keuangan yang sesuai dengan pedoman yang berlaku dan layak serta dapat dipertanggungjawabkan serta mengarahkan kepada penerapan sistem akuntansi keuangan pemerintah yang berkualitas. Laporan keuangan pemerintah Kabupaten Indragiri Hilir bisa dikatakan cukup baik. Akan tetapi tetap harus menerapkan sistem pengendalian intern dengan tegas agar apabila ada pelanggaran atau terjadinya temuan-temuan Pemerintah Kabupaten Indragiri Hilir bisa segera berbenah.

Fenomena pelaporan keuangan pemerintah di Kabupaten Indragiri Hilir merupakan suatu hal yang menarik untuk dikaji lebih lanjut. Dari https://m.goriau.com yang berhasil diakses, Pemerintah Kabupaten Indragiri Hilir kembali sukses meraih opini wajar tanpa pengecualian dari Badan Pemeriksa Keuangan (BPK) Republik Indonesia (RI) Perwakilan Provinsi Riau. Predikat WTP tersebut diraih Pemerintah Kabupaten Indragiri Hilir untuk keempat kalinya pada tahun ini. Predikat WTP kinerja keuangan ini diperoleh Pemerintah Kabupaten Indragiri Hilir atas Laporan Keuangan Pemerintah Daerah Tahun 2019 Pemerintah Kabupaten Kota Se-Provinsi Riau. Ketika BPK memberikan opini wajar tanpa pengecualian (WTP) terhadap Laporan Keuangan Pemerintah Daerah (LKPD) maka dapat dikatakan bahwa laporan keuangan entitas tersebut disajikan secara wajar dan berkualitas. Fenomena pelaporan keuangan pemerintah ini sangat menarik dikaji lebih lanjut. Laporan yang berkualitas juga sangat dipengaruhi oleh sistem pengendalian intern pemerintah dan penerapan sistem akuntansi keuangan.

Pengendalian intern dibutuhkan agar mudah dalam menemukan atau menganalisis permasalahanpermasalahan yang ada atau permasalahanyang mungkin akan timbul dalam proses pencapaian tujuan sehingga pencapaian tujuan bisa kita ketahui secara jelas. Dalam meningkatkan kinerja pemerintah yang paling umum terjadi ialah korupsi, kesalahan administrasi serta pengelolaan keuangan yang tidak berjalan dengan baik (Triyanti, 2017). Proses pengendalian menyatu pada tindakan dan kegiatan yang dilakukan secara terus menerus secara konsisten oleh pimpinan dan seluruh pegawai. Oleh karena itu, yang menjadi pondasi dari pengendalian ini adalah orang-orang (SDM) didalam organisasi yang membentuk lingkungan pengendalian yang baik dalam mencapai sasaran dan tujuan yang ingin dicapai instansi pemerintah.

Penerapan sistem akuntansi keuangan yang akuntabel serta dengan pengendalian yang bersistem dan terorganisir akan mampu memberikan pengaruh terhadap kualitas laporan keuangan pemerintahan. Salah satu upaya untuk mewujudkan pengelolaan keuangan negara yang baik adalah penyampaian laporan keuangan pemerintah yang disusun dengan menerapkan standar akuntansi pemerintahan. Penerapan sistem akuntansi keuangan yang terarah diatur dalam Standar Akuntansi Pemerintahan (SAP) merupakan prinsipprinsip akuntansi yang harus diterapkan untuk memperoleh hasil laporan keuangan yang berkualitas. Laporan keuangan merupakan laporan yang terstruktur mengenai posisi keuangan dan transaksi-transaksi yang dilakukan oleh suatu entitas pelaporan. Dengan demikian, SAP merupakan persyaratan yang mempunyai kekuatan hukum dalam upaya meningkatkan kualitas laporan keuangan pemerintah di Indonesia. Kemudian dalam proses penyusunan laporan keuangan daerah, harus didukung oleh teknologi informasi yang memadai. Menurut Sugiyanto (2002) dalam Efendi dkk (2017), volume transaksi keuangan pemerintah menunjukkan kuantitas yang semakin besar dan kompleks. Oleh karena itu, peningkatan volume transaksi yang semakin besar dan kompleks tentu harus diikuti dengan pemanfaatan teknologi informasi dalam pengelolaan keuangan pemerintah.

Syahadatina dan Fitriyana (2016), yang menyatakan bahwa sitem pengendalian intern berpengaruh secara signifikan terhadap kualitas laporan keuangan pemerintah daerah dan Triwahyuni (2016), menyatakan hasil penelitian bahwa penerapan sistem akuntansi keuangan daerah memilik pengaruh terhadap kualitas laporan keuangan daerah. Selain itu dalam penelitian Ardianto (2019), sistem pengendalian intern pemerintah tidak berpengaruh signifikan terhadap kualitas laporan keuangan pemerintah daerah dan sistem akuntansi keuangan daerah tidak berpengaruh terhadap kualitas laporan keuangan pemerintah daerah. Ketidakkonsistenan penelitian tersebut membuat penulis tertarik untuk meneliti kembali Pengaruh Sistem Pegendalian Interent Dan Sistem Akuntansi Keuangan Daerah Terhadap Kualitas Laporan Keuangan Pemerintah Kabupaten Indragiri Hilir (Studi Empiris Pada OPD Kabupaten Indragiri Hilir).

Dengan adanya beberapa temuan dari penelitian sebelumnya serta melihat dari beberapa fenomena yang terjadi dikabupaten Indragiri Hilir, memberikan ketertarikan untuk melanjutkan penelitian ini dengan melihat aspek-aspek dalam sistem pengendalian intern dan penerapan sistem akuntansi keuangan daerah yang terjadi didalam kualitas laporan keuangan pemerintah daerah. Laporan keuangan merupakan media bagi sebuah entitas dalam hal ini pemerintah untuk mempertanggungjawabkan kinerja keuangannya kepada publik. Pemerintah harus mampu menyajikan laporan keuangan yang mengandung informasi keuangan yang berkualitas. Laporan keuangan pemerintah daerah sebagai bentuk pertanggungjawaban pelaksanaan APBD 
harus disusun atau dihasilkan dari sebuah sistem akuntansi pemerintah daerah yang handal, yang bisa dikerjakan secara manual ataupun menggunakan aplikasi komputer.

Pemerintah telah banyak mengeluarkan berbagai bentuk sistem yang seluruhnya berakhir pada tujuan untuk mewujudkan tata kelola penyelenggaraan pemerintah yang baik. Penyelenggaraan pemerintahan tentu memiliki kegiatan yang cukup banyak dan sangat luas, mulai dari perencanaan, pelaksanaan, pertanggung jawaban, pengawasan hingga evaluasi. Maka untuk dapat mewujudkan tata kelola penyelenggaraan pemerintah yang baik tersebut pemerintah membentuk suatu sistem yang dapat mengendalikan seluruh kegiatan penyelenggaraan pemerintahan

\section{TINJAUAN PUSTAKA}

\subsection{Sistem Pengendalian Intern}

Peraturan Pemerintah Nomor 60 Tahun 2008 Sistem Pengendalian Intern Pemerintah adalah proses yang integral pada tindakan dan kegiatan yang dilakukan secara terus menerus oleh pimpinan dan seluruh pegawai untuk memberikan keyakinan memadai atas tercapainya tujuan organisasi melalui kegiatan yang efektif dan efisien, keandalan pelaporan keuangan, pengamanan aset negara, dan ketaatan terhadap peraturan perundang-undangan.

SPIP bertujuan untuk memberikan keyakinan yang memadai bagi tercapainya efektivitas dan efisiensi pencapaian tujuan penyelenggaraan pemerintahan Negara, keandalan pelaporan keuangan, pengamanan asset Negara, dan ketaatan terhadap peraturan perundang-undangan. Indikator Sistem Pengendalian Intern sesuai dengan Peraturan Pemerintah Nomor 60 Tahun 2008 tentang Sistem Pengendalian Intern Pemerintah (SPIP) terdiri dari lima indikator, yaitu lingkungan pengendalian, penilaian risiko, kegiatan pengendalian, informasi dan komunikasi, pemantauan pengendalian intern. Kelima indikator sistem pengendalian intern yaitu lingkungan pengendalian, penilaian risiko, kegiatan pengendalian, informasi dan komunikasi, serta pemantauan pengendalian intern merupakan unsur yang terjalin erat satu dengan yang lainnya. Tiap-tiap indikator ini memiliki sub indikatornya masing-masing, dalam PP No. 60 Tahun 2008 yang akan diuraikan sebagai berikut :

1. Lingkungan pengendalian

2. Penilaian risiko

3. Aktivitas pengendalian

4. Informasi dan komunikasi

5. Pemantauan pengendalian intern

\subsection{Standar Akuntansi Pemerintah Daerah}

Standar Akuntansi Pemerintahan PP No. 71 Tahun 2010 pasal 1 ayat (3) tentang Standar Akuntansi Pemerintahan yang selanjutnya disingkat SAP,adalah prinsip-prinsip akuntansi yang diterapkan dalam menyusun dan menyajikan laporan keuangan pemerintah. Dengan demikian SAP merupakan persyaratan dan dasar yang mempunyai kekuatan hukum dalam upaya meningkatkan kualitas pelaporan keuangan pemerintah di Indonesia. SAP diterapkan dalam lingkup pemerintahan yaitu pemerintah pusat, pemerintah daerah, dan satuan organisasi di lingkungan pemerintah pusat/daerah.

Penerapan Standar Akuntansi Pemerintahan harus mengacu pada Peraturan Pemerintah yang berlaku, dalam hal ini Peraturan Pemerintah Nomor 71 Tahun 2010 tentang Standar Akuntansi Pemerintahan yang merupakan pengganti Peraturan Pemerintah Nomor 24 Tahun 2005 tentang Standar Akuntansi Pemerintahan. Sampai dengan tahun anggaran 2013, pemerintah daerah masih menerapkan SAP berdasarkan Peraturan Pemerintah Nomor 24 Tahun 2005 tentang Standar Akuntansi Pemerintahan. Perbedaan fundamental Peraturan Pemerintah Nomor 71 Tahun 2010 dengan Peraturan Pemerintah Nomor 24 Tahun 2005 terletak pada basis pencatatan transaksi dan jenis laporan keuangan.

Berdasarkan Peraturan Menteri Nomor 64 Tahun 2013 tentang Standar Akuntansi Pemerintahan, yang selanjutnya disingkat SAP adalah prinsip-prinsip akuntansi yang diterapkan dalam menyusun dan menyajikan laporan keuangan pemerintah. Sebagai implikasi ditetapkannya SAP maka pemerintah pusat dan pemerintah daerah telah mempunyai pedoman dalam menyusun dan menyajikan laporan keuangan sesuai dengan prinsip-prinsip yang berlaku. Terdapat 12 Penerapan Standar Akuntansi Pemerintah Yaitu :

1. PSAP Nomor 01 Tentang Penyajian Laporan Keuangan

2. PSAP Nomor 02 Tentang Laporan Realisasi Anggaran

3. PSAP Nomor 03 Tentang Laporan Arus Kas

4. PSAP Nomor 04 Tentang Catatan atas Laporan Keuangan

5. PSAP Nomor 05 Tentang Akuntansi Persediaan

6. PSAP Nomor 06 Tentang Akuntansi Investasi

7. PSAP Nomor 07 Tentang Aktiva Tetap

8. PSAP Nomor 08 Tentang Konstruksi dalam Pengerjaan

9. PSAP Nomor 09 Tentang Akuntansi Kewajiban

10. PSAP Nomor 10 Tentang Koreksi Kesalahan Perubahan Kebijakan Akuntansi dan Peristiwa Luar Biasa

11. PSAP Nomor 11 Tentang Laporan Keuangan Konsolidasian

12. PSAP Nomor 12 Tentang Laporan Operasional 


\subsection{Sistem Akuntansi Keuangan Daerah}

Menurut Abdul Hakim mengutip dari Kepmendagri No.29 Tahun 2002 pasal 70 ayat (1) Sistem Akuntansi Keuangan Daerah adalah sistem akuntansi yang meliputi proses pencatatan, penggolongan, penafsiran, peringkasan transaksi atau kejadian keuangan serta pelaporan keuangannya dalam rangka pelaksanaan APBD, dilaksanakan dalam prinsip-prinsip akuntansi yang berterima umum.

Menurut Nordiawan (2006) Sistem Akuntansi Keuangan Daerah (SAKD) adalah serangkaian prosedur yang saling berhubungan, yang digunakan sesuai dengan skema menyeluruh yang ditunjukan untuk menghasilkan informasi dalam bentuk laporan keuangan yang akan digunakan pihak intern dan ekstern pemerintah daerah untuk mengambil keputusan ekonomi.

Berdasarkan Permendagri No. 13 Tahun 2006 yang terdapat pada pasal 232 menyatakan bahwa Sistem Akuntansi Keuangan Daerah merupakan serangkaian prosedur mulai dari proses pengumpulan data, pencatatan, pengikhtisaran, sampai dengan pelaporan keuangan dalam rangka pertanggungjawaban pelaksanaan APBD yang dapat dilakukan secara manual atau menggunakan komputer.

\subsection{Kualitas Laporan Keuangan Pemerintah}

Harahap (2013), kualitas laporan keuangan merupakan kriteria persyaratan laporan akuntansi keuangan yang dianggap dapat memenuhi keinginan para pemakai atau pembaca laporan keuangan. Sedangkan menurut Bastian (2010), bahwa kualitas laporan keuangan adalah hasil akhir dari proses akuntansi yang menyajikan informasi yang berguna untuk pengambilan keputusan oleh berbagai pihak yang berkepentingan.

Faktor-faktor yang mempengaruhi kualitas laporan keuangan intansi menurut Setyowati (2016), yaitu:

1. Pemanfaatan sistem informasi akuntansi keuangan Daerah

2. Kompetensi sumber daya Manusia

3. Peran Internal Berikut penjelasannya dari faktor-faktor kualitas laporan keuangan adalah:

a. Pemanfaataan Peraturan Pemerintah Republik Indonesia Nomor 56 Tahun 2005 tentang sistem informasi keuangan daerah (SIKDA) menyebutkan bahwa sistem informasi keuangan daerah adalah suatu sistem mendokumentasikan, mengadministrasikan, serta mengolah data pengelolaan keuangan daerah dan data terkait lainnya menjadi informasi yang disajikan kepada masyarakat dan sebagai bahan pengambilan keputusan dalam rangka perencanaan, pelaksanaan dan pelaporan pertanggungjawaban pemerintah daerah. Sedangkan informasi keuangan daerah adalah segala informasi yang berkaitan dengan keuangan daerah yang diperlukan dalam rangka penyelenggaraan sistem informasi keuangan daerah.

b. Kompetensi Sumber Daya Manusia, Kompetensi adalah karakteristik dasar dari seseorang yang memungkinkan mereka mengeluarkan kinerja superior dalam pekerjaannya. Makna kompetensi mengandung bagian kepribadian yang mendalam dan melekat pada seseorang dalam perilaku yang dapat diprediksi pada berbagai keadaan dan tugas pekerjaan. Prediksi siapa yang berkinerja baik dan kurang baik dapat diukur dari kriteria atau standar yang digunakan.

c. Peran internal auditing merupakan suatu aktivitas independen, keyakinan objektif dan konsultasi yang dirancang untuk memberikan tambah dan mengingatkan operasi organisasi. Dengan demikian internal auditing membantu organisasi dalam mencapai tujuannya dengan menerapkan pendekatan yang sistematis dan berdisiplin untuk mengevaluasi dan meningkatkan efektivitas proses pengelolaan risiko kecukupan kontrol dan pengelolaan organisasi.

\subsection{Hipotesa}

$\mathrm{H}_{1}$ : Pengendalian Intern berpengaruh terhadap Kualitas Laporan Keuangan Pemerintah pada OPD Kabupaten Indragiri Hilir.

$\mathrm{H}_{2}$ : Penerapan sistem akuntansi keuangan daerah berpengaruh terhadap Kualitas Laporan Keuangan Pemerintah pada OPD Kabupaten Indragiri Hilir.

\section{METODOLOGI PENELITIAN}

\subsection{Populasi Dan Sampel}

Populasi dalam penelitian ini adalah seluruh kantor Organisasi Perangkat Daerah (OPD) Kabupaten Indragiri Hilir. Pengambilan sampel dalam penelitian ini menggunakan purposive sampling dimana menurut Indriantoro dan Supomo (2013) merupakan teknik penentuan sampel atas dasar pertimbangan. Adapun pertimbangan pemilihan sampel tersebut memiliki beberapa kriteria. Adapun kriterianya sebagai berikut :

1. Responden dalam penelitain ini adalah para pegawai/staf yang melaksanakan fungsi akuntansi/tata usaha keuangan dan para pegawai/staf pemegang kas/bendahara penerimaan maupun pengeluaran pada OPD di Kabupaten Indragiri Hilir.

2. Responden dalam penelitian ini adalah kepala sub bagian keuangan dan kepala OPD di OPD Kabupaten Indragiri Hilir selaku pengambil keputusan dalam menggunakan anggaran dan menggunakan barang. 


\subsection{Definisi Operasional dan Pengukuran Variabel}

\section{Sistem Pengendalian Intern $\left(\mathbf{X}_{1}\right)$}

Sistem Pengendalian intern Pemerintah adalah proses yang integral terhadap tindakan dan kegiatan yang dilakukan secara terus menerus oleh pimpinan dan seluruh pegawai untuk memberikan keyakinan memadai atas tercapainya tujuan organisasi melalui kegiatan yang efektif dan efisien, keandalan pelaporan keuangan, pengamanan aset negara, dan ketaatan terhadap peraturan perundang-undangan. Dalam penelitian ini variabel sistem pengendalian intern memiliki 5 indikator berdasarkan Peraturan Pemmerintah Nomor 60 Tahun 2008 tentang Sistem Pengendalian Intern Pemerintah yaitu lingkungan pengendalian, penilaian risiko, kegiatan pengendalian, infomasi dan komunikasi serta pematauan. Untuk mengukur variabel Sistem Pengendalian intern ini terdiri dari 10 item pertanyaan yang diadopsi dari penelitian Syahadatina dan Fitriyana (2016). Skala yang digunakan untuk variabel sistem pengendalian intern yaitu skala likert.

\section{Penerapan Sistem Akuntansi Keuangan Daerah $\left(\mathbf{X}_{2}\right)$}

Badan Akuntansi Keuangan Negara (BAKUN) Departemen Keuangan RI (2001) menjelaskan suatu sistem informasi yang menggabungkan proses pencatatan, pengikhtisaran dan pelaporan data yang berkaitan dengan keuangan dari suatu entitas sehingga dapat menghasilkan informasi keuangan yang dapat digunakan sebagai dasar dalam pengambilan keputusan oleh pihak-pihak yang berkepentingan. Dalam penelitian ini variabel sistem akuntansi keuangan daerah diukur menggunakan kuesioner yang mengacu pada penelitian Nurachman (2016). Indikator untuk variabel ini yaitu pencatatan, pengikhtisaran, dan pelaporan terdiri dari 16 pernyataan positif. Skala yang digunakan untuk variabel ini yaitu skala likert .

\section{Kualitas Laporan Keuangan Pemerintah Daerah (Y)}

Harahap (2013), kualitas laporan keuangan merupakan kriteria persyaratan laporan akuntansi keuangan yang dianggap dapat memenuhi keinginan para pemakai atau pembaca laporan keuangan. Kualitas laporan keuangan pemerintah daerah menurut Peraturan Menteri Dalam Negeri Nomor 64 Tahun 2013 memiliki 4 indikator yaitu relevan, andal, dapat dibandingkan, dan dapat dipahami. Pengukuran variabel ini memiliki 8 item pertanyaan yang diadopsi dari penelitian Syahadatina dan Fitriyana (2016). Skala yang digunakan untuk variabel yaitu dengan menggunakan skala likert

\section{HASIL PENELITIAN DAN PEMBAHASAN}

\subsection{Gambaran Umum Objek Penelitian}

Objek pada penelitian ini adalah Organisasi Perangkat Daerah (OPD) kabupaten Indragiri Hilir. OPD di Kabupaten Indragiri Hilir berjumlah 55 Unit OPD yang terdiri dari 35 Dinas/Intansi dan 20 Kecamatan. Penelitian ini dilakukan pada 35 Organisasi Perangkat Daerah (OPD) di lingkungan Pemerintah Daerah Kabupaten Indragiri Hilir. Responden dalam penelitian ini adalah para pegawai/staf yang melaksanakan fungsi akuntansi/tata usaha keuangan dan para pegawai/staf pemegang kas/bendahara penerimaan maupun pengeluaran pada OPD di Kabupaten Indragiri Hilir dan kepala sub bagian keuangan dan kepala OPD di OPD Kabupaten Indragiri Hilir selaku pengambil keputusan dalam menggunakan anggaran dan menggunakan barang.

\subsection{Statisktik Deskriptif}

Tabel 4.1

Pengujian Statistics Descriptive

Descriptive Statistics

\begin{tabular}{ll|l|l|l||l} 
& N & Minimum & Maximum & Mean & Std. Deviation \\
\hline SPI & 50 & 29.00 & 49.00 & 41.5400 & 4.51397 \\
\hline SAK & 50 & 48.00 & 78.00 & 64.8200 & 7.88098 \\
\hline Kualitas Lap Keuangan & 50 & 24.00 & 40.00 & 33.2400 & 3.95154 \\
\hline Valid N (listwise) & 50 & & & & \\
\hline
\end{tabular}

Sumber : Data Olahan SPSS 26, 2021

Statistik deskriftif dari variabel-variabel yang digunakan dalam penelitian ini menunjukan rata-rata variabel sistem pengendalian intern 41,54 dengan std. deviasinya 4,51397. Rata- rata variabel Sistem Akuntansi Keuangan adalah 64,82 dengan std. deviasinya 7,880. Rata-rata Kualitas Laporan Keuangan adalah 33,24 dengan std. deviasinya 3,951. Adapun hasil maximum untuk variabel Sistem Pengendalian Intern 42 dengan minimum 29, maximum untuk variabel sistem Akuntansi keuangan adalah 78 dengan minimum 48, dan maximum untuk Kualitas Laporan Keuangan adalah 40 dengan minimum 24.

\subsection{Pengujian Validitas Dan Reabilitas}

1. Pengujian Validitas

Pengujian validitas yang dilakukan dalam penelitian ini adalah dengan menghitung besarnya $r$ hitung setiap butir pertanyaan, dimana hasil perhitungan dapat secara langsung dilihat pada kolom output corrected item total correlation. Penyebaran kuesioner khusus dalam uji validitas dan reliabilitas diambil langsung dari 
50 responden dengan nilai $r$ tabel sebesar 0,2787. Dalam penelitian ini $\mathrm{r}$ hitung dari masing masing intrumen lebih besar dari pada $\mathrm{r}$ tabel.

\section{Pengujian Reabilitas}

Pengujian ini dilakukan terhadap pernyataan-pernyataan yang sudah memiliki validitas. Kegunaannya adalah untuk mengetahui sejauh mana hasil pengukuran tetap konsisten bila dilakukan pengukuran dua kali atau lebih terhadap gejala yang sama. Uji reliabilitas dilakukan dengan menggunakan koefisien Cronbach Alpha lebih besar 0,6 dengan nilai variabel Sistem Pengendalian Intern sebesar 0,829, Sistem Akuntansi Keuangan dengan nilai 0,949, Kualitas Laporan Keuangan Pemerintah dengan nilai 0,903. Sehingga bermakna instrumen pertanyaan yang digunakan dalam riset ini sudah reliabel atau dapat diandalkan.

\subsection{Uji Asumsi Klasik}

1. Uji Normalitas

Gambar 4.1

Uji Normalitas

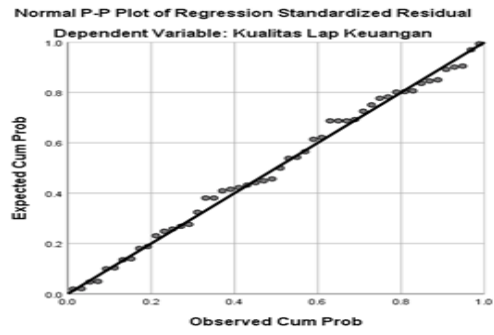

Sumber : Data Olahan SPSS 26, 2021

2. Uji Heteroskedastisitas

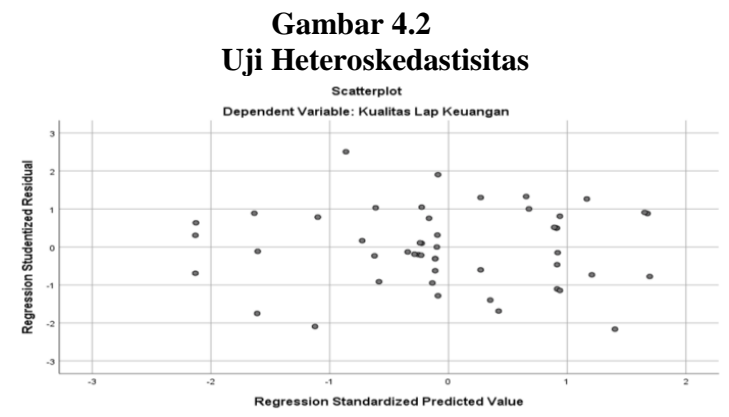

Sumber : Data Olahan SPSS 26, 2021

3. Uji multikolinearitas

Dijelaskan bahwa nilai VIF, sistem pengendalian intern sebesar 1.150 dan penerapan SAKD senilai 1,097, yaitu dengan nilai $<10$ dan nilai tolerance sistem pengendalian intern senilai 0.870 , dan penerapan SAKD senilai 0,845 yaitu dengan nilai $>0,1$ bahwa tidak terjadi adanya korelasi di antara variabel. Jadi pengujian dijelaskan berarti tidak adanya gejala multikolinearitas di antara variabel independen.

\subsection{Hasil Uji Hipotesa}

1. Uji regresi Linear Berganda

Hubungan antara variabel independen dan variabel dependen dapat dirumuskan kedalam persamaan sebagai berikut:

Tabel 4.2

Uji Regresi Linear Berganda Coefficients $^{\mathrm{a}}$

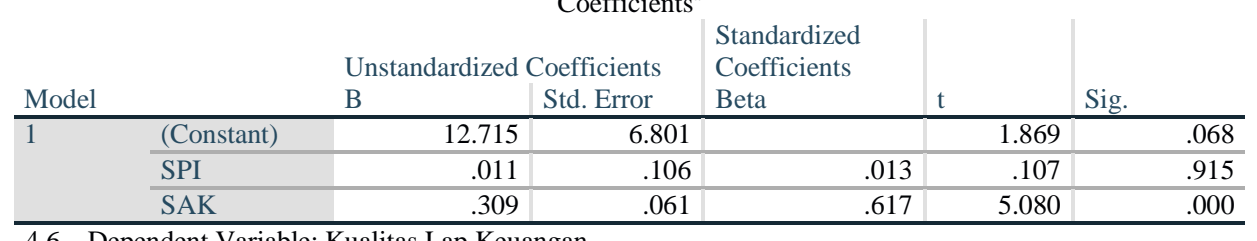

4.6 Dependent Variable: Kualitas Lap Keuangan

Sumber: Data Olahan SPSS 26, 2021

Ira Gustina, Pengaruh Sistem Pengendalian Intern Dan Penerapan Sistem Akuntansi Keuangan Daerah Terhadap Kualitas Laporan Keuangan Pemerintah Kab. Indragiri Hilir 
Berdasarkan tabel 4.2 maka persamaan regresi linear berganda penelitian ini adalah sebagai berikut:

$$
\mathrm{Y}=12.715+0.011 \mathrm{X}_{1}+0.309 \mathrm{X}_{2}+\varepsilon
$$

2. $\mathrm{Uji}-\mathrm{t}$

Pengujian ini dilakukan untuk menguji apakah setiap variabel bebas yaitu sistem pengendalian internal dan sistem akuntansi keuangan daerah mempunyai pengaruh yang signifikan terhadap variabel terikat yaitu kualitas laporan keuangan secara parsial. Sesuai dengan hipotesa yang diajukan dalam penelitian ini, maka berdasarkan tabel diatas secara terperinci dihasilkan pengujian sebagai berikut:

1. Hasil analisis Sistem Pengendalian Interen terdapat nilai sig 0,915 dimana nilai sig ini lebih besar dari nilai probabilitas 0,05 atau nilai $0,915>0,05$, maka $\mathrm{H}_{1}$ ditolak dan Ho diterima. Variabel $\mathrm{X}_{1}$ mempunyai t hitung yakni 0,107 dengan t tabel 2,0281. Jadi thitung $X_{1} 0,107>t$ tabel 2,0281. Hal tersebut membuktikan bahwa variabel Sistem Pengendalian Interen merupakan variabel yang tidak berpengaruh secara parsial terhadap kualitas laporan keuangan pada organisasi Perangkat Daerah Kabupaten Indragiri Hilir.

2. Hasil analisis penerapan sistem akuntansi keuangan terdapat nilai sig 0,008 dimana nilai sig ini lebih kecil dari nilai probabilitas 0,05 , atau nilai $0,000<0,05$, maka $\mathrm{H}_{2}$ diterima dan Ho ditolak. Variabel $\mathrm{X}_{2}$ mempunyai t hitung yakni 5,080 dengan $t$ tabel 2,0281. Jadi t-hitung $X_{2} 2,810>t$ tabel 2,0281. Hal tersebut membuktikan bahwa variabel penerapan sistem akuntansi keuangan variabel yang berpengaruh secara parsial terhadap kualitas laporan keuangan Pada Operasi Perangkat Daerah Kabupaten Indragiri Hilir.

\section{Koefisien Determinasi $\left(\mathrm{R}^{2}\right)$}

Koefisien determinasi dilihat dari adjusted R square yang artinya seberapa besar kontribusi variabel terikat. Uji koefisien determinasi yaitu mengukur seberapa jauh kemampuan model dalam menerangkan variasi variabel dependen. Adapun hasil dari uji dari koefisien determinasi melalui program SPSS versi 26 dapat dilihat pada tabel dibawah ini:

Tabel 4.3

Uji Coefisien Determinasi

\begin{tabular}{|c|c|c|c|c|c|}
\hline \multicolumn{6}{|c|}{ Model Summary } \\
\hline Model & $\mathrm{R}$ & R Square & $\begin{array}{l}\text { Adjusted } \quad \text { R } \\
\text { Square }\end{array}$ & $\begin{array}{l}\text { Std. Error of the } \\
\text { Estimate }\end{array}$ & Durbin-Watson \\
\hline 1 & $.613^{\mathrm{a}}$ & .376 & .349 & 3.18791 & 1.307 \\
\hline
\end{tabular}

a. Predictors: (Constant), SAK, SPI

b. Dependent Variable: Kualitas Lap Keuangan

Sumber : Data Olahan SPSS 26, 2021

Pada tabel diatas menunjukan bahwa nilai adjusted $\mathrm{R}_{2}$ sebesar 0,349 hal ini berarti 34,9\% Kualitas Laporan Keuangan dipengaruhi oleh dua variabel penjelas yaitu Sistem Pengendalian Intern dan Penerapan Sistem Akuntansi Keuangan. Sisanya $65,1 \%$ dipengaruhi oleh variabel lain yang tidak disetarakan dalam variabel penelitian ini.

\subsection{Pembahasan}

\section{Pengaruh Sistem Pengendalian Internl Terhadap Kualitas Laporan Keuangan}

Berdasarkan hasil pengujian hipotesa secara individual, variabel sistem pengendalian intern tidak berpengaruh terhadap Kualitas Laporan Keuangan Pemerintah Daerah Kabupaten Indragiri Hilir sehingga $\mathrm{H}_{1}$ ditolak. Sistem pengendalian intern yang baik belum tentu akan meningkatkan kualitas laporan keuangan pemerintah Kabupaten Indragiri Hilir. Hal tersebut juga menunjukan kualitas laporan keuangan pemerintah daerah tidak hanya dinilai dari efektivitas pengendalian internalnya saja, sehingga aparatur pemerintah harus mampu memenuhi aspek-aspek lain untuk menghasilkan laporan keuangan yang berkualitas. Aspek-aspek tersebut diantaranya kesesuaian dengan standar akuntansi pemerintah, kecukupan pengungkapan (adequate disclosure) dan kepatuhan terhadap peraturan perundang-undangan.

Penelitian ini sejalan dengan penelitian Triono dan Dewi, (2020) yang menyatakan bahwa sistem pengendalian intern tidak berpengaruh positif terhadap kualiatas laporan keuangan pemerintah daerah Dan penelitian ini tidak sejalan dengan penelitian Munasyir (2015) yang menyatakan bahwa sistem pengendalian intern berpengaruh positif dan signifikan terhadap kualitas Laporan Keuangan Pemerintah Daerah.

Fokus penelitian kali ini ialah Pemerintahan Daerah, dimana Pemerintahan Daerah selaku salah satu organisasi yang memiliki peranan penting terhadap keberlangsungan hidup dari masyarakatnya (dalam hal ini masyarakat Kabupaten Indragiri Hilir) selalu dituntut untuk mengedepankan akuntabilitas dan transparansi. Demi bisa mengedepankan akuntabilitas dan tranparansi tersebut, maka Pemerintah Daerah perlu mempersiapkan laporan keuangan. Mamesah dalam Halim (2012), mengatakan bahwa tata usaha keuangan daerah dibagi menjadi dua golongan, yaitu tata usaha umum dan tata usaha keuangan. Tata usaha umum menyangkut kegiatan surat-menyurat, mengagenda, mengekspedisi, menyimpan surat-surat penting atau mengarsipkan serta kegiatan dokumentasi lainnya. Sedangkan tata usaha keuangan pada intinya adalah tata buku yang merupakan rangkaian kegiatan yang dilakukan secara sistematis di bidang keuangan berdasarkan 
prinsip-prinsip, standar-standar tertentu serta prosedur- prosedur tertentu sehingga dapat memberikan informasi aktual di bidang keuangan. Tata usaha keuangan atau tata buku inilah yang sering disebut dengan akuntansi keuangan daerah. Sistem Pengendalian Internal bertujuan dapat memberikan keyakinan yang memadai bagi tercapainya efektivitas dan efisiensi pencapaian tujuan penyelenggaraan pemerintahan Negara, keandalan pelaporan keuangan, pengamanan asset Negara, dan ketaatan terhadap peraturan perundangundangan.

\section{Pengaruh Penerapan Sistem Akuntansi Keuangan Daerah Terhadap Kualitas Laporan Keuangan}

Berdasarkan hasil pengujian hipotesa secara individual, Sistem Akuntansi Keuangan Daerah memiliki pengaruh terhadap Kualitas Laporan Keuangan Pemerintah Daerah Kabupaten Indragiri Hilir, sehingga $\mathrm{H}_{2}$ diterima. Hal ini menunjukkan bahwa semakin baik dalam menerapkan Sistem Akuntansi Keuangan Daerah maka semakin baik Kualitas Laporan Keuangan Pemerintah Daerah. Suatu informasi yang disajikan membutuhkan sebuah sistem dalam penyusunannya. Menurut Nordiawan, (2006) Sistem Akuntansi Keuangan Daerah (SAKD) adalah serangkaian prosedur yang saling berhubungan, yang digunakan sesuai dengan skema menyeluruh yang ditunjukan untuk menghasilkan informasi dalam bentuk laporan keuangan yang akan digunakan pihak intern dan ekstern pemerintah daerah untuk mengambil keputusan ekonomi.

Penerapan sistem akuntansi keuangan daerah diperlukan untuk menghasilkan keluaran berupa laporan keuangan pemerintah daerah yang tepat dan akurat. Laporan keuangan daerah yang akurat menjadi dasar untuk pengambilan keputusan. Oleh karena itu, laporan keuangan pemerintah daerah harus berkualitas. Jadi untuk memperoleh kualitas laporan keuangan daerah sesuai Standar Akuntansi Pemerintahan harus melalui Penerapan Sistem Akuntansi Keuangan Daerah. Hasil dari penelitian ini sejalan dengan penelitian yang dilakukan oleh Triwardana (2017). Sistem Akuntansi Keuangan Daerah (SAKD) merupakan sistem akuntansi yang terdiri dari seperangkat kebijakan, standar dan prosedur yang dapat menghasilkan laporan yang relevan, andal dan tepat waktu untuk menghasilkan informasi dalam bentuk laporan keuangan yang akan digunakan oleh pihak intern dan ekstern pemerintah daerah untuk mengambil keputusan ekonomi.

\section{KESIMPULAN DAN SARAN}

1. Populasi dalam penelitian ini adalah penjabat dan pegawai pengelola keuangan pada Organisasi Perangkat Daerah (OPD) Pemerintah Daerah Kabupaten Indragiri Hilir.

2. Variabel sistem pengendalian intern tidak berpengaruh terhadap Kualitas Laporan Keuangan Pemerintah Daerah Kabupaten Indragiri Hilir. Hal tersebut menunjukan kualitas laporan keuangan pemerintah daerah tidak hanya dinilai dari efektivitas pengendalian internalnya saja, sehingga aparatur pemerintah harus mampu memenuhi aspek-aspek lain untuk menghasilkan laporan keuangan yang berkualitas. Aspek-aspek tersebut diantaranya kesesuaian dengan standar akuntansi pemerintah, kecukupan pengungkapan (adequate disclosure), dan kepatuhan terhadap peraturan perundangundangan.

3. Sistem Akuntansi Keuangan Daerah berpengaruh terhadap Kualitas Laporan Keuangan Pemerintah pada OPD Kabupaten Indragiri Hilir. Hal ini menunjukkan bahwa semakin baik dalam menerapkan Sistem Akuntansi Keuangan Daerah maka semakin baik Kualitas Laporan Keuangan Pemerintah Daerah. Untuk memperoleh kualitas laporan keuangan daerah sesuai Standar Akuntansi Pemerintahan harus melalui Penerapan Sistem Akuntansi Keuangan Daerah.

\section{DAFTAR PUSTAKA}

Ardianto. 2019. Pengaruh Penerapan Standar Akuntansi Pemerintahan, Pemanfaatan Teknologi Informasi, Kompetensi Sumber Daya Manusia, Penerapan Sistem Pengendalain Intern Pemerintah dan Sistem Akuntansi Keuangan Daerah Terhadap Kualitas Laporan Keuangan Pemerintah Daerah (Studi Empiris Pada SKPD Wilayah Kabupaten Tangerang). Jurnal Bina Akuntansi Vol. 6 No. 1. Universitas Multimedia Nusantara.

Bastian, Indra. 2010. Akuntansi Sektor Publik Suatu Pengantar Edisi Ketiga. Erlangga: Jakarta.

Efendi, Loli, dkk. 2017. Faktor-Faktor yang Mempengaruhi Kualitas Pelaporan Keuangan Daerah (Studi Pada Satuan Kerja Perangkat Kabupaten Aceh Tengah). Jurnal Perspektif Ekonomi Darussalam. ISSN. 2502-6976.

Halim, Abdul dan Muhammad Syam Kusufi. 2012. Akuntansi Keuangan Daerah. Salemba Empat, Jakarta Harahap, Sofyan Syafri. 2013. Analisa Kritis atas Laporan Keuangan. PT Raja Grafindo Persada: Jakarta. Indrianto dan Supomo. 2013. Metodologi Penelitian Bisnis. BPFE Yogyakarta: Yogyakarta

Munasyir. 2015. Pengaruh Penerapan Standar Akuntansi Pemerintah dan Sistem Pengendalian Intern Pemerintah Terhadap Kualitas Laporan Keuangan Satuan Kerja Perangkat Daerah Di Kabupaten Aceh Utara. Jurnal Magister Akuntansi Pascasarjana. Universitas Syiah Kuala.

Mardiasmo, 2012. Otonomi dan Manajemen Keuangan Daerah. Andi: Yogyakarta.

Nordiawan, Deddi. 2006. Akuntansi Sektor Publik. Jakarta: Salemba Empat

Nurachman, Dwi Aditya. 2016. Pengaruh Akuntabilitas Publik Dan Sistem Akuntansi Keuangan Daerah Terhadap Kualitas Laporan Keuangan Daerah (Survei pada DPKAD dan Inspektorat Kota Bandung). Skirpsi. Fakultas Ekonomi dan Bisnis Unpas Bandung 
Setyowati, Lilis. dkk. 2016. Faktor-Faktor Yang Mempengaruhi Kualitas Laporan Keuangan Pemerintah Daerah Kota Semarang. Volume 20, No.2, Hal. 179-19

Syahadatina, Rika dan Ismantika Fitriyana. 2016. Pengaruh Sumber Daya Manusia dan Pengendalian Intern terhadap Kualitas Laporan Keuangan Pemerintah Daerah. Jurnal Akuntansi dan Investasi, Vol 1, No 1. Universitas Madura.

Triono, Suryo dan Septiana Novita Dewi. 2020. Pengaruh Sistem Pengenalian Intern Terhadap Kualitas Laporan Keuangan Pemerintah Daerah. Jurnal Akuntansi dan Pajak, 21 (1), 2020, 213-220. STIE AUB Surakarta.

Triyanti. 2017. Pengaruh Kompetensi Sumber Daya Manusia Di Bidang Akuntansi Dan Sistem Pengendalian Internal Terhadap Kualitas Laporan Keuangan Pemerintah Daerah (Studi Kasus Pada Pemerintah Kabupaten Magelang).Universitas Negeri Yogyakarta.

Triwahyuni. 2016. Pengaruh Penerapan Standar Akuntansi Pemerintahan (SAP), Kompetensi Sumber Daya Manusia (SDM) dan Penerapan Sistem Akuntansi Keuangan Daerah Terhadap Kualitas Laporan Keuangan SKPD (Studi Pada Pemerintah Daerah Kota Dumai). JOM Fekon Vol. 3 No. 1 (Februari) 2016. Universitas Riau, Pekanbaru.

Triwardana. 2017. Pengaruh Penerapan Standar Akuntansi Pemerintahan, Penerapan Sistem Akuntansi Keuangan Daerah Dan Kompetensi Sumber Daya Manusia Terhadap Kualitas Laporan Keuangan SKPD (Studi Pada Pemerintah Daerah Kabupaten Kampar). JOM Fekon Vol. 4 No. 1 (Februari) 2017. Universitas Riau.

Peraturan Pemerintah Nomor 60 Tahun 2008 tentang Elemen Sistem Pengendalian Intern.

Peraturan Pemerintah Nomor 71 Tahun 2010 tentang Standar Akuntansi Pemerintahan.

Peraturan Menteri Dalam Negeri Nomor 64 Tahun 2013 tentang Penerapan Standar Akuntansi Berbasis Akrual pada Pemerintah Daerah

https://m.goriau.com/berita/baca/untuk-keempat-kalinya-pemkab-inhil-sukses-raih-opini-wtp.html Kempat kalinya Pemerintah Kabupaten Indragiri Hilir sukses raih WTP.

www.bpk.go.id

Ira Gustina, Pengaruh Sistem Pengendalian Intern Dan Penerapan Sistem Akuntansi Keuangan Daerah Terhadap Kualitas Laporan Keuangan Pemerintah Kab. Indragiri Hilir 